\title{
Advantages of Cotton Based Intercropping System: A Review
}

\author{
Shravan Kumar Panda ${ }^{1}$, Pritam Panda ${ }^{1}$, Biswajit Pramanick ${ }^{2}$, Tanmoy Shankar ${ }^{1}$, \\ Subhashisa Praharaj ${ }^{1}$, Binoy Kumar Saren ${ }^{3}$, Harun I Gitari ${ }^{4}$, Koushik Brahmachari ${ }^{5}$, \\ Akbar Hossain $^{6}$ and Sagar Maitra ${ }^{1^{*}}$
}

${ }^{1}$ Centurion University of Technology and Management, Odisha, India

${ }^{2}$ Dr. Rajendra Prasad Central Agriculture University, Pusa, Bihar, India

${ }^{3}$ Institute of Agriculture, Visva-Bharati, Sriniketan, West Bengal, India

${ }^{4}$ School of Agriculture and Enterprise Development, Kenyatta University, Nairobi, Kenya

${ }^{5}$ Bidhan Chandra Krishi Viswavidyalaya, Mohanpur, India

${ }^{6}$ Bangladesh Wheat and Maize Research Institute, Dinajpur, Bangladesh

Corresponding author: sagar.maitra@cutm.ac.in

Received: $11-10-2019$

Revised: $20-11-2020$

Accepted: 10-12-2020

\begin{abstract}
Intercropping provides ample scope to incorporate at least two or more crops at a time in same piece of land aiming at higher productivity from unit land area through optimized utilization of available resources. Selection of crops, planting geometry and optimum stand and crop maturity are important factors influencing success of intercropping system. Upland cotton, being a moderately long duration and widely spaced crop and having moderate growth rate during early stage, offers suitability for adoption of intercropping. Previous research indicates that under cotton-based intercropping system there is efficient use of resources resulting in not only high productivity from unit area but also in high profitability. The current review article highlights the advantages of cotton-based intercropping system based on previous research findings.
\end{abstract}

Keywords: Cotton, Intercropping system, Considerations for intercropping, Advantages

Cotton, an important fiber and cash crop of India, is grown in about 12 million ha with a production of 35.9 million bales (170 $\mathrm{kg}$ each) and productivity of $510 \mathrm{~kg} \mathrm{ha}^{-1}$. Nonetheless, this yield is still lower than the world average of $792 \mathrm{~kg}$ lint ha-1 (GoI, 2017; Blaise and Kranthi, 2019). India is the largest producer of cotton in the world producing $25 \%$ of the global lint. The crop plays an important role agricultural economy supporting about 60 million Indians along its value chain. It is a key raw material in cotton textile industry. To supply the requirements of the industry, nearly 15 million growers are engaged in cultivation of the crop (Gandhi and Jain, 2016). There are four cultivated species of cotton in India viz. Gossypium arboreum, G. herbaceum, G. hirsutum and G. barbadense; of which G. hirsutum (commonly known as upland and American cotton) accounts for $97 \%$ of the cultivated cotton in India. About two-third of cotton area in the country is rainfed and faces different abiotic stresses during the growing season.

As a widely spaced crop, cotton provides ample scope for adoption of intercropping system. Intercropping is a traditional farming practice of growing of two or more crop species concurrently so that they coexist for a significant part of their growing cycle and that they interact among themselves and with agro-ecosystem (Reddy et al. 1980; Maitra et al. 2019; Gitari et al. 2020; Maitra and Gitari, 2020). Intercropping is one of the profoundly encouraging methodologies for

How to cite this article: Panda, S.K., Panda, P., Pramanick, B., Shankar, T., Praharaj, S., Saren, B.K., Gitari, I.H., Brahmachari, K., Hossain, A. and Maitra, S. (2020). Advantages of Cotton Based Intercropping System: A Review. International Journal of Bioresource Science, 7(2): 51-57.

Source of Support: None; Conflict of Interest: None $\odot$ 
improving crop yields and profitability from unit area (Maitra et al. 2000, 2001a; Nyawade et al. 2020). Small and marginal cotton growers of the country face different constrains mainly due to climatic aberrations and increase in input costs which results in decreased profits. Under such circumstances, intercropping cotton with other crops provides additional return, improves soil quality (if legume is included as intercrop), reduces climatic risks and chance of crop failure, enhances biodiversity and ensures greater use of resources (Maitra et al. 1999, 2001b; Maitra and Ray, 2019).

\section{Considerations for Intercropping System}

The success or failure of intercropping system is reliant some considerations given that the companion crops that are grown in the mixture may strive spatially and temporally amongst species for common pool of resources. Therefore, crop choice is important factor in intercropping. Further, planting geometry and plant stand of crops impact benefits of intercropping system (Reddy et al. 1980; Maitra et al. 2020a). Time of planting and crop maturity are also important considerations. Moreover, farmers' economic situation and preference crop species are also factors influencing intercropping system.

\section{Choice of crops in intercropping}

The success of intercropping system enormously relies upon choice of crops in a combination. Under ideal crop combination, the corresponding and synergistic impact of intercropping is reflected in improved yield and economic benefits (Nyawade et al. 2018; Maitra and Gitari, 2020). Cotton is normally cultivated with an inter-row spacing of between 60 and $90 \mathrm{~cm}$ and interplant spacing of $20 \mathrm{~cm}$ given that it shows moderate development at its initial growth stages. Inter-row space which, remains empty for around 60 days after planting can be used to grow the intercrops. Short duration and quick developing legumes such as black gram, green gram, soybean and cowpea, and vegetables (namely, beet, onion and so on) are suitable crops for cotton-based intercropping (Giri and Upadhyay, 1980; Maitra et al. 2001b). Cotton based intercropping framework with vegetable is also effective for augmentation of greater productivity and return from unit area (Sankaranarayanan et al. 2012).

\section{Crop maturity}

The maturity of crop is prime in implementation of an intercropping. In most cases, it is recommended that the companion crops under an intercropping system should have different peak period of growth, otherwise these component crops will compete among themselves for available resources (Manasa et al. 2018). The complementary association of crop species helps the cropping system to flourish their morphological expressions and yield increase is noted. Therefore, crops of various duration and maturity are selected to obtain complementary benefits. The short statured legumes and vegetables with short duration can easily be incorporated as intercrops with comparatively tall base crops (Kumar et al., 2003).

\section{Plant density}

Optimum stand establishment is required to obtain an optimum yield. In intercropping system, more than one crops are grown in the same field simultaneously and thus there may be decrease in population of crops in comparison to the pure stand of each species (Gitari et al. 2018; Maitra et al. 2021). In the additive series of intercropping, full population of the base crop is maintained and still intercrops are accommodated especially in the inter row spaces. The intercrop is sown by adjusting row spacing or changing planting geometry (Gitari et al. 2020). Intercrop population may be less or equal to the pure stands. To create greater space in between rows of base crops, paired row planting can also be done (Maitra et al. 2001b). In replacement series of intercropping system, the crops (two or more) chosen are known as component crops or intercrops. In such type of intercropping, a component crop is introduced by replacing the other such that none of the component crops are sown at $100 \%$ population as it is the case under pure stands. It is very clear that certain proportion of population of one crop component is sacrificed in order to introduce another component crop in its place. The competition between crop species in replacement series of intercropping is comparatively less as observed in additive series of intercropping. 


\section{Competition functions and assessment of Advantages of cotton-based intercropping system}

For assessment of advantages of intercropping, different competition functions have been developed. Most remarkable was the proposal of the land equivalent ratio (LER) and afterwards widespread application of the LER was noted to evaluate the performance of an intercropping system (Willey and Osiru, 1972; Willey, 1979; Beets, 1982). Later a number of researchers reviewed these works and endorsed the concept of LER (Francis, 1986; Ofori and Stern, 1987; Francis et al. 1976; Fukai, 1993). Not only the LER, there are also some other concepts are developed over the time by the researchers to describe the competitive relationship and yield advantages. Following are some of the competition functions and the results of cottonbased intercropping system showing advantages over pure stand.

\section{Land Equivalent Ratio (LER)}

Willey and Osiru (1972) gave the idea of the Land Equivalent Ratio (LER) and it is described as the proportionate land area required under pure stand of crop species to yield the same produce as obtained under an intercropping at the same management level (Willey et al. 1983). In a replacement series of intercropping with two crops at the ratio of 1:1, the LER can be calculated by following expression.

$$
L E R=\frac{Y a b}{Y a a}+\frac{Y b a}{Y b b}=L a+L b
$$

Where, $\mathrm{Y} a b$ is the yield of " $a$ " crop grown in association with " $b$ " crop and Y $\mathrm{Y} a$ is the yield of " $b$ " crop grown in association with " $a$ " crop. Yaa and Y $b b$ represent the yields of " $a$ " and " $b$ " crops grown in pure stand, respectively. The modified formula for any other situation:

$$
L E R=\frac{Y a b}{Y a a \times Z a b}+\frac{Y b a}{Y b b \times Z b a}
$$

The LER specifies the benefits of an intercropping to utilize the limited available resources against their sole cropping (Mead and Willey, 1980). The value of LER more than unity (1.0) indicates the advantages of the intercropping system (Ofori and Stern, 1987). LER values of cotton-based intercropping experiments presented in Table 1 indicate advantages of intercropping.

\begin{tabular}{|c|c|c|c|}
\hline $\begin{array}{l}\text { Intercropping } \\
\text { system }\end{array}$ & Ratio & LER & References \\
\hline Cotton + groundnut & $2: 1$ & 2.28 & Maitra et al. 2001b \\
\hline Cotton + cowpea & $1: 1$ & 1.4 & Rusinamhodzi et al. 2006 \\
\hline Cotton + sorghum & $1: 1$ & 1.46 & Aasim et al. 2008 \\
\hline Cotton + Cowpea & $2: 2$ & 2.03 & Mwamlima et al. 2016 \\
\hline Cotton + Clusterbean & $1: 1$ & 1.46 & Kumar et al. 2017 \\
\hline Cotton + Cowpea & $1: 1$ & 1.46 & Kumar et al. 2017 \\
\hline Cotton + blackgram & $1: 2$ & 1.51 & $\begin{array}{l}\text { Vasavi and Sreerekha, } \\
2017\end{array}$ \\
\hline Cotton + Cowpea & $1: 2$ & 1.44 & Rajpoot et al. 2018 \\
\hline Cotton + Okra & $1: 2$ & 1.44 & Rajpoot et al. 2018 \\
\hline
\end{tabular}

Table 1: LER of cotton-based intercropping system

\section{Area Time Equivalent Ratio (ATER)}

Hiebsch (1978) developed the concept of Area Time Equivalent Ratio (ATER) in which the duration of crops (starting from seeding to harvest) was considered. The ATER is calculated by the following formula:

$$
A T E R=\frac{(R Y c \times t c)+(R Y p \times t p)}{T}
$$

Where, $R Y=$ Relative yields of crop species " $c$ " and " $p$ ", $t=$ duration (in days) for species " $c$ " and " $p$ " and $T=$ duration (in days) for the intercropping system.

In the LER, area is only taken into consideration and not the time. But in the ATER, both the area and time are considered on the basis of crop duration or occupancy of land by the crops in mixture. Like LER, when the ATER value exceeds 1.0 considered as advantageous. Some ATER values from the

\begin{tabular}{|c|c|c|c|}
\hline $\begin{array}{l}\text { Intercropping } \\
\text { system }\end{array}$ & Ratio & ATER & References \\
\hline Cotton + groundnut & $1: 2$ & 1.50 & Maitra et al. 2001b \\
\hline Cotton + ricebean & $2: 1$ & $1: 11$ & Khan et al. 2004 \\
\hline Cotton + cowpea & $1: 1$ & 1.13 & Aasim et al. 2008 \\
\hline Cotton + Cowpea & $2: 2$ & 1.55 & Mwamlima et al. 2016 \\
\hline Cotton + blackgram & $1: 2$ & 1.12 & $\begin{array}{l}\text { Vasavi and Sreerekha, } \\
2017\end{array}$ \\
\hline Cotton + okra & $1: 2$ & 1.20 & Rajpoot et al. 2018 \\
\hline
\end{tabular}
previous experiments are presented in Table 2.

Table 2: ATER of cotton-based intercropping system 


\section{Cotton equivalent yield}

Crop equivalent yield (CEY) is the conversion of crop yields into one form to compare the crops cultivated under mixed cropping or intercropping or sequential cropping (De Wit, 1960). The conversion of yield is done in the form of base crop (A) equivalent yield by considering the intercrop yield and market price of ' $\mathrm{A}$ ' and associated intercrops. The CEY is calculated by converting the yield of intercrop(s) into the yield of ' $A$ ' crop expressed in $\mathrm{kg} \mathrm{ha}^{-1}$ on the basis of prevailing prices with the help of following formula.

'A' Crop equivalent yield $=$

$$
\frac{\text { Yield of intercrop }}{\text { Market price of 'A' crop }} \times \text { Market price of intercrop }
$$

Where, crop equivalent yield is expressed in $\mathrm{kg} \mathrm{ha}^{-1}$, market prices of base crop (A) and intercrops are calculated on the basis of prevailing market price (in rupees $\mathrm{ha}^{-1}$ ). When the base crop equivalent yield is attained more in intercropping compared to the base crop yield, intercropping combination is considered as beneficial. Table 3 shows benefits of intercropping in terms of cotton equivalent yield (CEY).

Table 3: Cotton equivalent yield (CEY) from experimental findings

\begin{tabular}{|c|c|c|c|}
\hline Crop & Ratio & $\begin{array}{l}\text { CEY (Kg } \\
\left.\text { ha }^{-1}\right)\end{array}$ & References \\
\hline $\begin{array}{l}\text { Cotton + green } \\
\text { gram }\end{array}$ & $1: 2$ & 1888 & Maitra et al. 2001b \\
\hline $\begin{array}{l}\text { Cotton + mung } \\
\text { bean }\end{array}$ & $2: 4$ & 2951 & Tabib et al. 2014 \\
\hline Cotton + onion & $1: 1$ & 2396 & $\begin{array}{l}\text { Jayakumar and } \\
\text { Surendran, } 2016\end{array}$ \\
\hline $\begin{array}{l}\text { Cotton }+ \text { moth } \\
\text { bean }\end{array}$ & $1: 2$ & 714 & Patel et al. 2017 \\
\hline Cotton + soybean & $4: 10$ & 9147 & Turkhede et al. 2017 \\
\hline
\end{tabular}

\section{Multifaceted advantages of cotton-based intercropping system}

Intercropping is one of the suitable options to enhance diversity in an agricultural ecosystem and even some of the ecosystem services. Intercropping can assure ecological balance, more utilization of resources, enhancement of crop productivity and thus sustainability in agricultural production.
There are many researches showing superiority of intercropping system over the sole cropping. Intercropping assures efficient utilization of the resources and more yield than sole cropping (Willey, 1979; Andersen et al. 2007; Mucheru-Muna et al. 2010; Gitari et al. 2019). Yield advantage pronounces due to better use of growth resources such as light, water, and nutrients by the intercrop over time and space. Such advantages are also reflected in economics of cotton cultivation (Maitra et al. 1999). Moreover, inclusion of legumes in cotton-based intercropping system can improved soil fertility.

Intercropping is an appropriate practice for managing the weeds since sufficient ground area is covered by crops hence decreasing weed development. Compared to the pure stand of cotton, under intercropping system, weed population and weed biomass are reduced. Weed populace including grasses, sedges and broad-leaved weeds were diminished under paired row cotton and blackgram intercropping (Sankaran and Balasubramanian, 1982). Chatterjee and Mandal (1992) had brought up depressive impact on weed development because of intercropping. Before introduction of Bt cotton, the pesticide consumption in cotton was half of the country's plant protection chemicals use. Boll worm complexes were the prime threat before. Researchers noted that Heliothis (Helicoverpa) population was less in intercropped cotton (Laster and Fun, 1972). Suresh and Dason (1996) recorded the least infestation of leaf hopper and bollworms in cotton when intercropped with black gram, green gram or cluster bean. Intercropping of cowpea and green gram decreased the sucking type insects as observed by Mote et al. (2001). Due to creation of functional diversity in intercropping system the pest population dynamics is modified to ensure use of less quantity of plant protection chemicals.

\section{CONCLUSION}

Intercropping system, the traditional farming practice, offers ample scope for utilization of available resources by inclusion of mixed species. The crops in an intercropping system are chosen expecting complementarity among the species in mixed stand and proper planting geometry is adopted to accommodate two or more crops. Cotton-based intercropping system is popular in India and research evidences clearly indicated 
greater resource use efficiency in terms of LER, ATER and CEY. These benefits are also reflected into economics of cotton cultivation. Further, functional diversity is created by cultivation of diversified crops simultaneously that reduces weeds and pests population. Thus, adoption of intercropping system may be a suitable option to cotton growers for enhancement of yield output from unit area as well as agricultural sustainability.

\section{REFERENCES}

1. Aasim, M., Umer, E.M. and Karim, A. 2008. Yield and competition indices of intercropping cotton (Gossypium hirsutum L.) using different planting patterns. Ankara üniversitesi ziraat fakültesi, 14(4): 326-333.

2. Andersen, M.K., Hauggaard-Nielsen, H., Høgh-Jensen, H. and Jensen, E.S. 2007. Competition for and utilisation of sulfur in sole and intercrops of pea and barley. Nutrient Cycling in Agroecosystems, 77: 143-153.

3. Beets, W.C. 1982. Multiple cropping and tropical farming systems. Boulder, Colorado: Westview Press, pp. 220.

4. Blaise, D. and Kranthi, K.R. 2019. Cotton production in India. In: Cotton production, Eds. Jabran, K. and Chauhan, B.S. pp.193-215. DOI: 10.1002/9781119385523.ch10.

5. Chatterjeeee, B.N. and Mandal, R.K. 1992. Present trends in research on intercropping. Indian Journal of Agricultural Science, 62: 507-518.

6. Francis, C.A. 1986. Introduction: distribution and importance of multiple cropping. Pages 1-20, In: Multiple cropping systems (Francis, C.A., Ed.). Macmillan Publishing Company, New York, USA.

7. Francis, C.A., Flor, C.A. and Temple, S.R. 1976. Adapting varieties for intercropping systems in the tropics. Pages 235-253, In: Multiple cropping (Papendick, R.I. et al. Eds.). American Society of Agronomy Special Publication: 27. Madison, Wisconsin.

8. Fukai, S. 1993. Intercropping-basis of productivity. Field Crops Research, 34: 239-245.

9. Gandhi, V.P. and Jain, D. 2016. Introduction of Biotechnology in India's Agriculture. Singapore: Springer DOI: 10.1007/978-981-10-1091-0_1.

10. Giri, A.N. and Upadhyay, U.C. 1980. Studies on painting pattern, intercropping and nitrogen economy of $\mathrm{H}-4$ cotton under rainfed condition. Indian Journal of Agronomy, 25: 71-76.

11. Gitari, H.I., Gachene, C.K.K., Karanja, N.N., Kamau, S., Nyawade, S., Sharma, K. and Schulte-Geldermann, E. 2018. Optimizing yield and economic returns of rain-fed potato (Solanum tuberosum L.) through water conservation under potato-legume intercropping systems. Agricultural Water Management. 208: 59-66.

12. Gitari, H.I., Nyawade, S.O., Kamau, S., Gachene, C.K.K., Karanja, N.N. and Schulte-Geldermann, E. 2019. Increasing potato equivalent yield increases returns to investment under potato-legume intercropping systems. Open Agriculture, 4: 623-629.

13. Gitari, H.I., Nyawade, S.O., Kamau, S., Karanja, N.N., Gachene, C.K.K., Raza, M.A., Maitra, S. and SchulteGeldermann, E. 2020. Revisiting intercropping indices with respect to potato-legume intercropping systems. Field Crops Research, 258: 107957.

14. GOI-Government of India. 2017. Agricultural Statistics at a glance. Ministry of Agriculture and Farmers Welfare, Department of Agriculture, Cooperation and Farmers Welfare, Directorate of Economics and Statistics, pp. 75.

15. Hiebsch, C.K. 1980. Principles of intercropping. "Effect of $\mathrm{N}$ fertilization and crop duration on equivalency ratios in intercrops versus monoculture comparisons." PhD Thesis. North Carolina State University, Raleigh, N. C., USA.

16. Jayakumar, M. and Surendran, U. 2016. Intercropping and balanced nutrient management for sustainable cotton production. Journal of Plant Nutrition, 40(5): 632-644.

17. Kumar, K.A., Reddy, M.D., Sankar, A.S. and Reddy, N.V. 2003. Yield and economics of maize (Zea mays) and soybean (Glycine max) in intercropping under different row proportions. Indian Journal of Agricultural Sciences, 73(2): 69-71.

18. Khan, M.B. and Khaliq, A. 2004. Studies on intercropping summer fodders in cotton. Journal of Research (Science), 15(3): 325-331.

19. Kumar, R., Turkhede, A.B., Meena, S. and Nagar, R.K. 2016. Performance of American cotton-legumes based intercropping system on nutrient uptake and soil nutrient status. Agricultural Science Digest, 36(3): 234-236.

20. Kumar, R., Turkhede, A.B., Nagar, R.K. and Nath, A. 2017. Effect of different intercrops on growth and yield attributes of American cotton under dryland condition. International Journal of Current Microbiology and Applied Science, 6(4): 754-761.

21. Laster, M.L. and Fun, R.E. 1972. Heliothis populations in cotton Sesame interplantings. Journal of Economic Entomology, 65: 1524-1525.

22. Maitra, S. 2020. Intercropping of small millets for agricultural sustainability in drylands: A review. Crop Research, 55(3-4): 162-171.

23. Maitra, S. and Ray, D.P. 2019. Enrichment of biodiversity, influence in microbial population dynamics of soil and nutrient utilization in cereal-legume intercropping systems: A Review. Int J Biores Sci., 6(1): 11-19.

24. Maitra, S., Barik, A., Samui, S.K. and Saha, D. 1999. Economics of cotton based intercropping system in the rice fallows of coastal Bengal- Sundarbans. Journal of Indian Society of Coastal Agricultural Research, 17(1-2): 299-304.

25. Maitra, S., Brestic, M., Hossain, A., Skalicky, M., Ondrisik, P., Gitari, H.I., Brahmachari, K., Shankar, T., Bhadra, P., Palai, J.B., Jena, J., Bhattacharya, U., Duvvada, S.K., Sagar, L., Masina Sairam, M., 2021. Intercropping-A low input agricultural strategy for food and environmental security. Agronomy, 11: 343. 
26. Maitra, S., Ghosh, D.C., Sounda, G. and Jana, P.K. 2001a. Performance of inter-cropping legumes in fingermillet (Eleusine coracana) at varying fertility levels. Indian Journal of Agronomy, 46(1): 38-44.

27. Maitra, S., Ghosh, D.C., Sounda, G. Jana, P.K. and Roy, D.K. 2000. Productivity, competition and economics of intercropping legumes in finger millet (Eleusine coracana) at different fertility levels. Indian Journal of Agricultural Science, 70(12): 824-828.

28. Maitra, S. and Gitari, H.I. 2020. Scope for adoption of intercropping system in organic agriculture. Indian Journal of Natural Sciences, 11(63): 28624-28631.

29. Maitra, S., Palai, J.B., Manasa, P. and Kumar, D.P. 2019. Potential of intercropping system in sustaining crop productivity. International Journal of Agriculture Environment and Biotechnology, 12(1): 39-45.

30. Maitra, S., Samui, R.C., Roy, D.K. and Mondal, A.K. 2001b. Effect of cotton based intercropping system under rainfed conditions in Sundarban region of West Bengal. Indian Agriculturist, 45(3-4): 157-162.

31. Maitra, S., Shankar, T. and Banerjee, P. 2020a. Potential and advantages of maize-legume intercropping system. In: maize - production and use (Ed. Hossain A), IntechOpen. doi: 10.5772/intechopen.91722.

32. Menon, M. 2003. Growing cotton: Finally, a loss of faith in chemical agriculture. Fanners' Forum, 3: 17-17.

33. Mote, U.N., Patil, M.B. and Tambe, A.B. 2001. Role of intercropping in population dynamic of major pest of cotton ecosystem. Annals of Plant Protection Sciences, 9: 36-40.

34. Mucheru-Muna, M., Pypers, P., Mugendi, D., Kung'u, J., Mugwe, J., Merckx, R. and Vanlauwe, B. 2010. A staggered maize legume intercrop arrangement robustly increases crop yields and economic returns in the highlands of Central Kenya. Field Crops Research, 115: 132-139.

35. Mwamlima, L.H., Kabambe, V.H., Mhango, W.G. and Nyirenda, G.K.C. 2016. Effects of intercropping on growth and yield of intercropped cotton (Gossypium hirsutum) and cowpea (Vigna unguiculata L. Walp) in Malawi. Agricultural Science Research Journal, 6(12): 303-312.

36. Nyawade, S., Gitari, H.I., Karanja, N.N., Gachene, C.K., Schulte-Geldermann, E., Sharma, K. and Parker, M. 2020. Enhancing climate resilience of rain-fed potato through legume intercropping and silicon application. Frontier in Sustainable Food Systems, 4: 566345.

37. Nyawade, O.S., Gitari, H.I., Karanja, N.N., Gachene, C.K.K., Schulte-Geldermann, E. and Parker, M. 2018. Intercropping potato with grain legumes for enhanced productivity and climate change adaptation in smallholder farms, Kenya. Proceedings of the Regional Universities Forum for Capacity Building in Agriculture (RUFORUM) Biennial Conference, October 22-26, 2018. Nairobi, Kenya. 17: 377-381.

38. Ofori, F. and Stern, W.R. 1987. Cereal-legume intercropping systems. Advances in Agronomy, 40: 41-90.
39. Patel, D.G., Patel, C.K., Singh, R.N. and Patel, N.I. 2017. Intercropping study in $B t$. cotton under rainfed condition of Kutch region of Gujarat (Gossypium hirsutum L.). International Journal of Science, Environment and Technology, 6(6): $3484-3488$.

40. Pilli Manasa, P., Maitra, S. and Reddy M.D. 2018. Effect of Summer Maize-Legume Intercropping System on Growth, Productivity and Competitive Ability of Crops, International Journal of Management, Technology and Engineering, 8(12): 2871-2875.

41. Rajpoot, S.K., Rana, D.S. and Choudhary, A.K. 2018. $B t$-cotton-vegetable-based intercropping systems as influenced by crop establishment method and planting geometry of $B t$-cotton in Indo-Gangetic plains region, Current Science, 115(3): 516-522.

42. Reddy, K., Reddy, K. and Reddy, M.D. 1980. Effects of intercropping on yield and returns in corn and sorghum. Experimental Agriculture, 16(2): 179-184.

43. Rusinamhodzi, L., Murwira, H.K. and Nyamangara, J. 2006. Cotton-cowpea intercropping and its $\mathrm{N}_{2}$ fixation capacity improves yield of a subsequent maize crop under Zimbabwean rain-fed conditions. Plant and Soil, 287: 327-336.

44. Sankaran, S. and Balasubramanian, N. 1982. Inter cropping of cotton. Cotton Development, 12: 23-23.

45. Sankaranarayanan, K., Nalayini, P. and Praharaj, C.S. 2012. Multi-tier cropping system to enhance resource utilization, profitablity and sustainability of $B t$ cotton (Gossypium hirsutum) production system. Indian Journal Agricultural Science, 82(12): 1044-50.

46. Smith, M.E. and Francis, C.A. 1986. Breeding for multiple cropping systems. In: Francis CA (Ed) Multiple Cropping Systems. MacMillan Publishing Company, New York, USA.

47. Suresh, S. and Dason, A.A. 1996. Effect of intercropping and time of sowing on cotton leaf hopper and bollworm. Madras Agricultural Journal, 83: 56-57.

48. Tabib, F.A.I., Karim, M.A., Haque, M.M., Khaliq, Q.A. and Solaiman A.R.M. 2014. Effect of planting arrangements on productivity of cotton + mungbean intercropping systemsm. Bangladesh Agronomy Journal, 17(1): 11-22.

49. Turkhede, A.B., Nagdeve, M.B., Karunakar, A.P., Gabhane, V.V., Mohod, V.D. and Mali, R.S. 2017. Diversification in cotton based cropping system under mechanization in rainfed condition of Vidarbha of Maharashtra, India. International Journal of Current Microbiology and Applied Sciences, 6(9): 2189-2206.

50. Vasavi, M. and Sreerekha, M. 2017. Effect of legume intercropping on competition indices and returns of Bt cotton. Journal of Cotton Research Development, 31(2): 279-282.

51. Willey, R.W., Natarajan, M., Reddy, M.S., Rao, M.R., Nambiar, P.T.C., Kannaiyan, J. and Bhatnagar, V.S. 1983. Intercropping studies with annual crops. In: Better Crops for Food, vol. 97. CIBA Foundation Symposium, pp. 83-100. 
52. Willey, R.W. 1979. Intercropping- its importance and research needs. Part 1: Competition and yield advantages. Field Crop Abstracts, 32: 1-10.
53. Willey, R.W. and Osiru, D.S.O. 1972. Studies on mixtures of maize and beans (Phasrolus vulgaris) with particular reference to plant population. Journal of Agricultural Science Cambridge, 79: 519-529. 
